\title{
Effect of feed, manure and their combination on the growth of Cyprinus carpio (L.) fry and fingerlings
}

\author{
Mohsen Saleh Hussein
}

Department of Animal Production (Fish Production), Faculty of Agriculture, Al-Azhar University, Egypt.

\section{ABSTRACT}

Two field experiments, each of 120-day, were conducted in twelve earthen ponds, each with dimensions $50 \times 20 \times 1.0 \mathrm{~m}$ (length $\mathrm{x}$ width $\mathrm{x}$ depth) were located at Serow Fish Farm, National Institute of Oceanography And Fisheries, Dakahlia Governorate, Egypt, with a view to study the effect of nutrient inputs (feed, manure and their combination) on the common carp (Cyprinus carpio) fry and fingerlings of the fish. The treatments consisted of control (C, T1), only feed (F, T2), only manure (M, T3) and manure plus feed (M+F (T4)). Poultry manure was applied in split doses to ponds of manure treatments $(\mathrm{M}$ and $\mathrm{M}+\mathrm{F})$. Fry (Experiment one) and fingerlings (Experiment two) of average initial weight $0.67 \mathrm{~g}$ and $3.2 \mathrm{~g}$ respectively, were stocked seven days after the initial manure application at 5 individuals $/ \mathrm{m} 2$. Fish in $\mathrm{F}$ and $\mathrm{M}+\mathrm{F}$ treatments were provided a fish meal based pelleted diet once daily in the morning at $5 \%$ of body weight. The most dominant genera of phytoplankton encountered were Microcystis, Anabaena and Microspora, while among the zooplankton, Keratella and Nauplii dominated. $\mathrm{M}+\mathrm{F}$ treatment had the highest plankton biomass $(\mathrm{P}<0.05)$. Significant $(\mathrm{P}<0.05)$ variation in both phyto and zooplankton dry weight was recorded with respect to the study period. Both feeding and manuring, individually and in combination, significantly improved $(\mathrm{P}<0.05)$ the growth of the fish. The highest specific growth rate, final fish weight, and gross production were recorded in $\mathrm{M}+\mathrm{F}$ treatment in both the experiments. The difference in survival among the control and treatments was not significant in experiment one $(\mathrm{P}>0.05)$, whereas $\mathrm{F}$ and $\mathrm{M}+\mathrm{F}$ treatments recorded lower survival $(\mathrm{P}<0.05)$ in the second experiment. Fish production was comparable under feed $(\mathrm{F})$ and manure $(\mathrm{M})$ treatments $(\mathrm{P}>0.05)$ in experiment one, but was significantly $(\mathrm{P}<0.05)$ different in experiment two. The increment in gross fish production over the control was 103.22 and $119.99 \%$ in feed, 77.30 and $59.44 \%$ in manure and 162.34 and $175.08 \%$ in $\mathrm{M}+\mathrm{F}$ treatments of the two experiments respectively. Carcass protein, fat and ash contents were significantly $(\mathrm{P}<0.05)$ higher in the three treatments as compared to the control.

Keywords: Common carp, Natural food, poultry manure, Supplementary feed; Fish production, carcass composition.

\section{INTRODUCTION}

Presently fish culture mainly depends on the application of organic fertilizers and to some extent on inorganic fertilizers. Fertilization enhances phytoplankton productivity in rearing and stocking ponds (New and Fedoruk, 2003; Bhakta et al., 2004, 2006). Phytoplankton and zooplankton represent rich source of protein (40$60 \%$ ) on dry weight basis which is sufficient for fish growth at low stocking densities (Silva and Anderson, 1995; Tabinda and Ayub, 2009, 2010; Sun et al., 2010). Artificial feed is seldom applied, due to the cost and herbivore nature of common carp (Cyprinus carpio). With the increase in fish demand trend has developed to culture fish more intensively to enhance the present level of fish production. Common 
carp has remained neglected in different culture practices, due to its in pond breeding habit and burrowing nature of feeding (Milstein et al., 2002). Recently some farmers are trying to introduce this fish to replace Cirrihinus mirgala (a bottom feeder) in combination with indigenous major carps in semi-intensive culture system. The adoption of this fish in polyculture seems more promising because it leads to higher fish production, due to its fast growth and hardy nature. Moreover it keeps nutrients in suspension, due its burrowing nature (Saikia and Das, 2008). Farmers can get double benefit in introducing the common carp in the pond as it increases the availability of nutrients for phytoplankton which in turn enhances fish production. According to Jain (2002), C. carpio has the ability to survive under various climatic conditions and is found to be most suitable for many fish farming systems. He is also of the opinion that $C$. carpio has the potential to improve conditions in pond bottom soil, as a result soil perturbation increases the oxygen transfer to the soil, decreases the concentration of toxic compounds and enables more efficient food web recycling and nutrient release (Ritvo et al., 2004; Da Silva et al., 2006; Rahman et al., 2008; Muhammad et al., 2011). Thus through polyculture, farmers can utilize all the different zones in pond water due to different feeding habits of fish and their occupation of different niches and polyculture with Cyprinus carpio. In this way farmers can also significantly cut down the overall production cost maintaining the desired water quality (Wahab et al., 2002; Milstein et al., 2002, Alim et al., 2005; Woynarovich, et al., 2011). According to Milstein et al. (2003), the common carp as a bottom feeder fish produces a fertilizing effect through a food web that benefits the filter feeding fishes and reduces the application of organic and inorganic fertilizers in aquaculture practices. It grows rapidly with high protein diet and minimum feed coefficient and is considered as a target cultured fish, and plays a key role in pond management. It stimulates efficiency of liming and nutrient availability in the bottom of ponds, so the inclusion of common carp in polyculture is economical to farmers as it lowers the input and management costs and it also benefits the pond water ecosystem (Wahab et al., 2002; Alim et al., 2005, Abbas et al., 2010).The production of fish pond depends on the vegetation, which is dependent on the nutrients in the ponds. It is not possible to increase the production of cultivated fish by giving them the greater quantities of natural food directly. Organic manures and chemical fertilizers can be used to increase the planktonic biomass, on which fish mainly feeds. It stimulates the growth of natural food by providing essential deficient elements, which are utilized by the phyto-and zooplanktons. Fertilization in fish farming is to improve water quality and to increase the variety and quantity of phytoplankton and zooplankton, which eventually leads to high fish yield and economic returns. Hence, the ultimate goal of fertilization is to achieve suitable environmental conditions for the production of natural food for fish, but in comparison with organic manure, fertilizers increase the level of primary productivity, abundance of algae, dissolved oxygen, pH and total phosphate (Afzal et al., 2007; Jana et al., 2001 Abbas et al., 2010). Sustainable and successful freshwater fish culture on scientific basis principally depends upon the use of adequate, economically viable and environment friendly artificial feeds. Since the feed costs vary between 40 to $60 \%$ of the total managerial expenditure in fresh water fish culture system, provision of artificial feed increases the fish growth and production in the fertilized ponds and results in higher growth rates and yields than fertilization alone (Diana et al., 1994). With a view of reducing feed input cost in aquacultural practices, it is necessary to develop better feeding strategies by incorporating plant based feed with animal protein based diets in feeding practices. Common carp fed with fish meal, rice bran, mustard oil cake 
showed 1.5 and 2.1 times higher fish yield than in the treatments without supplementary feed (Rahman et al., 2006). According to Azim et al. (2002) growth, specific growth rate of major carps were higher in fertilized ponds with the provision of supplemental feed than in control (fertilization alone). Nandeesha et al. (2001) also noted that the specific growth rates, protein efficiency ratio as well as growth rate were more pronounced in animal and plant based diet as compared to animal based diet. Fertilization and supplemental feeding are the two important management measures adopted in the semi-intensive system of carp and Tilapia culture in Egypt. Several studies focus on the role of fertilizers in fish production (Garg and Bhatnagar, 2000; Dhawan and Kaur, 2002; Das et al., 2005; Sayeed et al., 2007; Bwala and Omoregie, 2009; Hussein, 2009; Ponce Palafox, 2010. Priyadarshini1 et al., 2011) and of supplemental feed in systems receiving fertilizers (Aziz et al., 2002; Virk and Saxena, 2003; Ahmed etal., 2005; Waidbacher et al., 2006; Elnady et al., 2010). While supplemental feeding affects fish growth directly, fertilization contributes to growth via the planktonic natural food. In addition to acting as a food for fish, plankton perform other important functions in pond aquaculture: a net producer of dissolved oxygen, which is indispensable for fish growth (Teichert-Coddington and Green, 1993) and the most important sink of ammonia-nitrogen, which is excreted by the fish (Hargreaves, 1998; Jiménez-Montealegre, 2001). The FAO/AADCP Regional Expert Consultation has emphasized the need for a greater understanding of the role of natural food organisms in semi-intensive farming based on systems that optimize pond fertilization,in order to bring down the cost of fish production (NACA/FAO, 2000). The best way to reduce the cost of fish production is to minimize the use of supplemental food that can be best achieved by exploiting the synergetic interaction between natural food and supplemental feed. According to Moav et al. (1977), judicious organic manuring of fish ponds can eliminate the need for supplementary feeding. Increase in production by a given regime of supplementary feeding is of great economic importance, but is difficult to predict whether it is related to the amount of natural food available, the density of stocking or the range of other management variables. In the present work, an experiment has been conducted to evaluate the effect of supplementary feeding, manure and their combination in the monoculture of the common carp (Cyprinus carpio) fry and fingerlings carried out separately, to get an insight into their contribution to fish growth and production under different treatments.

\section{MATERIALS AND METHODS}

Description of the study area: The two parallel experiments were conducted in twelve nursing earthen ponds, each with dimensions $50 \times 20 \times 1.0 \mathrm{~m}$ (length $\mathrm{x}$ width $\mathrm{x}$ depth) located at Serow Fish Farm, National Institute of Oceanography And Fisheries, Dakahlia Governorate, Egypt. These ponds were firstly drained and cleaned, then supplied with drainage freshwater from El-Serow drainage canal to a depth of $0.7 \mathrm{~m}$. The experimental period lasted for 4 months (120 days, initiated on first May till first September). Ponds were sun and air dried for three weeks .Inlets of ponds were properly screened with gauze of fine mesh to avoid the entry of intruder into or exit of fish from the ponds. Tube well was used as source of water. All ponds where watered up to a level of $0.7 \mathrm{~m}$ and this water level was maintained throughout the experimental period. They were fertilized with organic manure to stimulate the productivity of the ponds. After two weeks of fertilization, ponds were stocked with 5000 Cyprinus carpiofry. At the time of stocking fish were weighed and measured. 
Fertilization of all these ponds was done daily with organic manure (poultry manure) $0.10 \mathrm{~g} \mathrm{~N} / 100 \mathrm{~g}$ fish body weight except control.

Feeds and feeding: Common carp fry (mean wt. $0.67 \mathrm{~g}$ ) in experiment one and fingerlings (mean wt. $3.2 \mathrm{~g}$ ) in experiment two were stocked in the ponds 7 days after manuring, at 5 individuals $/ \mathrm{m} 2$. Fish in $\mathrm{F}$ and $\mathrm{M}+\mathrm{F}$ treatments were provided with fish meal-based pelleted feed (Table 1) twice daily at 5\% of body weight. There were three experimental treatments and a control (T0). All the treatments including control had three replicates. The control did not receive any external input neither poultry manure nor supplementary feed while treatment $1(\mathrm{~T} 1)$ received regular applications of organic manure (M), treatment 2(T2) was offered supplementary feed only (F) containing 30\% protein (Islam, 2002), prepared (Rath, 2002) from different ingredients (Table 1) and T3 received both organic manure and supplementary feed $(\mathrm{M}+\mathrm{F})$ as mentioned in $\mathrm{T} 2$ above in triplicate .Supplementary feed was fed to fish daily $5 \%$ of their wet fish body weight. The amount of feed was increased fortnightly in proportionate to the weight increments. The feed was prepared using finelyground ingredients as per composition shown in Table 1.

They were mixed thoroughly with water to make a dough. The dough was then transferred to an aluminum container and steam cooked in a pressure cooker at 15 psi for 15 minutes. Vitamins and minerals mixture was mixed after cooling the dough. Pellets ( $2 \mathrm{~mm}$ diameter size) were prepared by a hand pelletizer and were dried in an oven at $40^{\circ} \mathrm{C}$.

Table 1: Composition of formulated feed

\begin{tabular}{|c|c|}
\hline Ingredient & $(\%)$ \\
\hline Fish meal & 30 \\
\hline Sunflower meal & 30 \\
\hline Rice bran & 10 \\
\hline Yellow corn & 28 \\
\hline Vitamin $^{1}$-mineral ${ }^{2}$ Mixture* & 2 \\
\hline
\end{tabular}

1- each one kg of vitamin mixture contains: vitamin A $72000 \mathrm{IU}$; E $60 \mathrm{mg}$; B1 6 mg; B3 12000 IU; B6 9mg; B12 0.06mg; C 12mg; Pantothenic acid $60 \mathrm{mg}$; Nicotinic acid 120mg; Folic acid 6mg; Biotin $0.3 \mathrm{mg}$; choline chloride $3 \mathrm{mg}$.

2- each one $\mathrm{kg}$ of mineral mixture contains: zinc sulfate heptahydrate $3.0 \mathrm{~g}$; cuprous chloride $0.10 \mathrm{~g}$; calcium phosphate monobasic $135.8 \mathrm{~g}$; calcium lactate $327.0 \mathrm{~g}$; ferric citrate $29.7 \mathrm{~g}$; potassium phosphate dibasic anhydrous $239.8 \mathrm{~g}$; sodium phosphate monobasic 87.2 ; sodium chroride $43.6 \mathrm{~g}$; magnesium sulfate $12.75 \mathrm{~g}$; aluminum chloride anhydrous $0.15 \mathrm{~g}$; potassium iodide $0.15 \mathrm{~g}$; cobalt chloride $1.0 \mathrm{~g}$; sodium selenite $11 \mathrm{mg}$ and L-cellulose $132.25 \mathrm{~g}$.

After every thirty days, the stocked fish were captured randomly with nylon net and wet body weight and total length was measured and recorded and the feed quantity was readjusted based on the weight recorded at each sampling. Trial continued for four months. At the termination of experiment all the fish from different treatments (with all the three replicates) were harvested, weighed individually and yield calculated and measured to assess the performance of various inputs on specific growth rate (SGR) and net fish yield.

Proximate composition of feed ingredients: The highest values of protein, fat and ash were recorded in fish meal and the lowest values of protein and fat in sunflower meal were recorded and determined. Rice bran had the highest fiber content, while Yellow corn had the highest level of NFE. The feed contained $28.87 \%$ protein, $5.1 \%$ fatand $30.54 \%$ NFE (Table 2). 
Table 2: Proximate compositions (\%) of ingredients and feed

\begin{tabular}{|l|l|l|l|l|l|}
\hline Parameter & Fish meal & sunflower meal & Rice bran & Yellow corn & Feed \\
\hline Moisture & $6.91 \pm 0.17$ & $6.58 \pm 0.18$ & $8.40 \pm 0.07$ & $9.99 \pm 0.42$ & $8.61 \pm 0.42$ \\
Crude protein & $51.83 \pm 0.55$ & $37.49 \pm 0.05$ & $4.92 \pm 0.55$ & $2.46 \pm 0.10$ & $28.87 \pm 0.10$ \\
Fat & $10.92 \pm 0.06$ & $6.79 \pm 0.10$ & $1.63 \pm 0.06$ & $0.53 \pm 0.10$ & $5.10 \pm 0.10$ \\
Ash & $25.79 \pm 0.03$ & $6.50 \pm 0.39$ & $17.69 \pm 0.03$ & $14.68 \pm 0.03$ & $14.68 \pm 0.03$ \\
Crude fibre & $1.90 \pm 0.15$ & $10.80 \pm 0.21$ & $31.80 \pm 0.15$ & $3.60 \pm 0.01$ & $12.20 \pm 0.01$ \\
Nitrogen-free extract & 2.65 & 31.84 & 35.56 & 81.68 & 30.54 \\
Gross energy (kJ/g) $^{2}$ & 16.41 & 16.59 & 7.86 & 14.81 & 13.76 \\
\hline
\end{tabular}

1- Calculated by differences.

2- Estimated according to Jobiling (1983).

Water quality analysis: Water quality parameters were measured weekly according to Boyd (1990 and 2000) and APHA (2000). Water quality samples were collected weekly from each pond manually from the middle of water column by putting a closed sample bottle and opened in the desired depth. This procedure was done in five different spots in each pond then samples were mixed in a plastic bucket and 1 liter sample was taken as a representative water sample of each pond. These samples were taken one week after fertilizer application. Analysis of water quality including temperature, $\mathrm{pH}$, dissolved oxygen (DO), free carbon dioxide $\mathrm{CO}_{2}$ ), total alkalinity, phosphate, ammonia, nitrate and nitrite were done at every week, collecting samples was done from the experimental ponds between 09.00 and $10.00 \mathrm{hr}$. Water temperature, dissolved oxygen and $\mathrm{pH}$ were measured at $9.00 \mathrm{~h}$ using a digital thermometer, and dissolved oxygen meter model Orion $835 \mathrm{~A}$, while $\mathrm{pH}$ was measured with a digital $\mathrm{pH}$ meter model Acumen 25 meter.

Qualitative and quantitative analysis of plankton: Phytoplankton and zooplankton samples were collected and measured fortnightly for qualitative analysis by towing $15 \mathrm{~mm}$ and $60 \mathrm{~mm}$ nets respectively. After collecting, zooplankton samples were preserved in LUGOL and phytoplankton in $4 \%$ formalin solution .Dry weight of plankton was also determined every fortnight by filtering 100 liters of water from each pond through a plankton net of $15 \mathrm{~mm}$ size and drying the filtrate in a hot-air oven at $80^{\circ} \mathrm{C}$, till a constant weight was obtained .The quantitative estimation of total plankton was done by the "Direct census method" (Jhingran et al., 1969).

Proximate composition: Proximate composition of feed ingredients, feed and fish carcass from experiment one was estimated. Fish carcass was obtained upon harvest by collecting five fish, each from the triplicate ponds and dried at $80^{\circ} \mathrm{C}$ to a constant weight. The dried carcass of each groupwas pooled together and ground. Moisture and ash contents were estimated according to AOAC (1995) methods. Crude protein, fat and fibre contents were analyzed using Kjeltec (Tecator, 1002 distilling unit), Soxtec (Tecator, 1043 extraction unit) and Fibretec (Tecator 1017 hot extractor) systems. Carbohydrate content was calculated as nitrogen free extract (NFE) by the difference method of Hastings (1976). The energy value of each ingredient as well as feed was obtained by multiplying protein, lipid and carbohydrate contents by factors 22.6, 38.9 and 17.2 respectively (Mayes, 1990) and expressed in kJ/g.

Fish growth parameters, survival and production calculation: After every one month, cultured fish species were captured randomly by using drag net from each experimental treatment and released back into their respective ponds after recording the data for wet body weight (WBW) and specific growth rate (SGR). After one month interval, on the basis of WBW, amount of organic fertilizer and supplementary feed added in fish ponds were determined for each treatment. Specific growth rate (SGR) was estimated by thefollowing formula given by Dhawan and Kaur (2002). 
SGR=In (Final wet body weight)-In (Initial wet body weight $) \times 100 /$ Time duration (days)

Survival rate and total fish production under different treatments: At the end of the experiment, total harvested

SR $(\%)=\%$ of live fish number at harvest.

Production $(\mathrm{g})=$ Mean body weight $(\mathrm{g}) \mathrm{x}$ Total number of viable fish at harvest.

Statistical analysis: Mean values of fish growth parameters at harvest, and carcass proximate composition were compared by one-way ANOVA. All plankton and water quality parameters were subjected to two-way ANOVA with treatment and sampling date as factors. When a main effect was significant, pair-wise comparison of treatment means was done by Duncan's multiple range test $(\mathrm{P}=0.05)$ (Duncan, 1955). All analyses were done using the ANOVA procedure of SAS program ver. 9.1 (SAS, 2005)

\section{RESULTS AND DISCUSSION}

\section{Water quality analysis During the Experimental period:}

Results presented in Table 3 revealed that average of water quality data variation for different water quality parameters of different treatments over the study period. Water quality parameters were within acceptable ranges for fish culture. There were no significant differences in water quality parameters between the different treatment ponds.

The values of water quality parameters monitored weekly ranged as follows. Water temperature: 27.96 to $28.16^{\circ} \mathrm{C}, \mathrm{pH}: 8.43$ to 8.58 , dissolved oxygen: 6.77 to $8.85 \mathrm{mg} / \mathrm{L}$, free carbon dioxide: 2.62 to $3.73 \mathrm{mg} / \mathrm{L}$, total alkalinity $\left(\mathrm{CaCO}_{3}\right): 139.20$ to $151.29 \mathrm{mg} / \mathrm{L}$, phosphate: 0.86 to $1.10 \mu \mathrm{g} / \mathrm{L}$, ammonia: 0.19 to $0.93 \mu \mathrm{g} / \mathrm{L}$, nitrate: 0.080 to $108 \mu \mathrm{g} / \mathrm{L}$, nitrite: 0.008 to $0.047 \mu \mathrm{g} / \mathrm{L}$ (Table 3). Alkalinity and phosphate contents were significantly $(\mathrm{P}<0.05)$ higher in $\mathrm{M}+\mathrm{F}$ treatment. $\mathrm{pH}$, free carbon dioxide, ammonia, nitrate and nitrite values did not differ $(\mathrm{P}>0.05)$ between the treatments and the control (Table 3). All the water quality parameters showed difference significant $(\mathrm{P}<0.05)$ variation. The interaction effect of treatment and day was significant only for $\mathrm{CO}_{2}(\mathrm{P}=0.04)$. $\mathrm{DO}, \mathrm{pH}$, alkalinity, nitrite and ammonia were the lowest on the first day of sampling.

Table 3: Water quality parameters (mean \pm S.E.) (Pooled data of the two experiments)

\begin{tabular}{|c|c|c|c|c|c|c|c|c|c|}
\hline Treatment & $\begin{array}{l}\text { Water } \\
\text { Temp. } \\
\left({ }^{\circ} \mathrm{C}\right)\end{array}$ & $\mathrm{pH}$ & $\begin{array}{l}\text { Dissolved } \\
\text { Oxygen } \\
(\mathrm{mg} / \mathrm{L})\end{array}$ & $\begin{array}{l}\text { Free } \mathrm{CO} 2 \\
(\mathrm{mg} / \mathrm{L})\end{array}$ & $\begin{array}{l}\text { Alkalinity } \\
(\mathrm{mg} / \mathrm{L})\end{array}$ & $\begin{array}{l}\text { Phosphate } \\
\text { (mg/L) }\end{array}$ & $\begin{array}{l}\text { Ammonia } \\
(\mathrm{mg} / \mathrm{L})\end{array}$ & $\begin{array}{l}\text { Nitrate } \\
(\mathrm{mg} / \mathrm{L})\end{array}$ & $\begin{array}{l}\text { Nitrite } \\
(\mathrm{mg} / \mathrm{L})\end{array}$ \\
\hline $\begin{array}{l}\text { Control } \\
\text { (T1) }\end{array}$ & $\begin{array}{l}28.14 \\
\pm 0.39 \mathrm{a}\end{array}$ & $\begin{array}{l}8.46 \\
\pm 0.10 \mathrm{a}\end{array}$ & $\begin{array}{l}8.09 \\
\pm 0.34 \mathrm{ab}\end{array}$ & $\begin{array}{l}3.73 \\
\pm 0.49 \mathrm{a}\end{array}$ & $\begin{array}{l}139.20 \\
\pm 2.17 \mathrm{c}\end{array}$ & $\begin{array}{l}0.86 \\
\pm 0.08 \mathrm{~b}\end{array}$ & $\begin{array}{l}0.37 \\
\pm 0.51 \mathrm{a}\end{array}$ & $\begin{array}{l}0.078 \\
\pm 0.21 \mathrm{a}\end{array}$ & $\begin{array}{l}0.039 \\
\pm 0.70 \mathrm{a}\end{array}$ \\
\hline $\begin{array}{l}\text { Feed } \\
\text { (T2) }\end{array}$ & $\begin{array}{l}28.16 \\
\pm 0.38 \mathrm{a}\end{array}$ & $\begin{array}{l}8.49 \\
\pm 0.09 \mathrm{a}\end{array}$ & $\begin{array}{l}6.77 \\
\pm 0.46 \mathrm{c}\end{array}$ & $\begin{array}{l}3.02 \\
\pm 0.47 \mathrm{a}\end{array}$ & $\begin{array}{l}141.67 \\
\pm 2.53 \mathrm{~b}\end{array}$ & $\begin{array}{l}0.96 \\
\pm 0.08 \mathrm{ab}\end{array}$ & $\begin{array}{l}0.93 \\
\pm 0.42 \mathrm{a}\end{array}$ & $\begin{array}{l}0.108 \\
\pm 0.21 \mathrm{a}\end{array}$ & $\begin{array}{l}0.047 \\
\pm 0.088 \mathrm{a}\end{array}$ \\
\hline $\begin{array}{l}\text { Manure } \\
\text { (T3) }\end{array}$ & $\begin{array}{l}28.16 \\
\pm 0.46 \mathrm{a}\end{array}$ & $\begin{array}{l}8.58 \\
\pm 0.07 \mathrm{a}\end{array}$ & $\begin{array}{l}7.18 \\
\pm 0.48 \mathrm{bc}\end{array}$ & $\begin{array}{l}2.62 \\
\pm 0.51 \mathrm{a}\end{array}$ & $\begin{array}{l}141.46 \\
\pm 2.00 \mathrm{~b}\end{array}$ & $\begin{array}{l}1.03 \\
\pm 0.08 \mathrm{ab}\end{array}$ & $\begin{array}{l}0.19 \\
\pm 0.44 \mathrm{a}\end{array}$ & $\begin{array}{l}0.080 \\
\pm 0.18 \mathrm{a}\end{array}$ & $\begin{array}{l}0.008 \\
\pm 0.63 \mathrm{a}\end{array}$ \\
\hline $\begin{array}{l}\text { Manure+ } \\
\text { Feed (T4) }\end{array}$ & $\begin{array}{l}27.96 \\
\pm 0.38 \mathrm{a}\end{array}$ & $\begin{array}{l}8.43 \\
\pm 0.08 \mathrm{a}\end{array}$ & $\begin{array}{l}8.85 \\
\pm 0.17 \mathrm{a}\end{array}$ & $\begin{array}{l}2.73 \\
\pm 0.53 \mathrm{a}\end{array}$ & $\begin{array}{l}151.29 \\
\pm 2.06 \mathrm{a}\end{array}$ & $\begin{array}{l}1.10 \\
\pm 0.09 \mathrm{a}\end{array}$ & $\begin{array}{l}0.34 \\
\pm 0.41 \mathrm{a}\end{array}$ & $\begin{array}{l}0.084 \\
\pm 0.17 \mathrm{a}\end{array}$ & $\begin{array}{l}0.024 \\
\pm 0.60 \mathrm{a}\end{array}$ \\
\hline
\end{tabular}

Different superscripts for values in the same column indicate significant $(\mathrm{P} \leq 0.05)$

Table (3) shows that the average values of water temperature and $\mathrm{pH}$ in the different treatments were similar during the experimental period and varied within a narrow range. $\mathrm{pH}$ was in the alkaline range throughout the experimental duration, indicating favorable conditions for biological production. This range was beneficial to fish culture in agreement with results of Hussein (2009) and Muhammad et al., 
(2011). Jhingran (1995) who observed that carps thrive well in the temperature range of $18.3^{\circ} \mathrm{C}$ to $37.8^{\circ} \mathrm{C}$. According to Farmanfarmain and Moore (1979), aquatic organisms can tolerate a wider range of temperatures, provided that fluctuations are not severe, sudden and of long duration. DO was high throughout the experimental duration and fluctuated between $6.77(\mathrm{~F})$ and $8.85 \mathrm{mg} / \mathrm{L}(\mathrm{M}+\mathrm{F}$ treatment). This reflects higher photosynthetic activity in manure plus feed treatment. Dissolved oxygen levels improved due to photosynthesis, while ammonia levels were reduced through assimilation by phytoplankton (Boyd, 1990).

Generally, cyprinids are capable of tolerating low oxygen levels of $3 \mathrm{mg} / \mathrm{L}$ (Huet, 1972). The highest value of total alkalinity was recorded in the (T4) treatment $(151.29 \mathrm{mg} / \mathrm{L})$ and the lowest occured in control T1 $(139.20 \mathrm{mg} / \mathrm{L})$. Total alkalinity was significantly greater where organic fertilizerd and feeds were applied to ponds (Kumar et al., 2005). Alkalinity increases with organic fertilization because bacterially generated $\mathrm{CO}_{2}$ from manure decomposition dissolves calcium and magnesium carbonate in pond water into calcium and magnesium bicarbonate (Boyd, 1990). Diana et al., (1994) reported that fertilization alone led to low alkalinity. Phosphorus was significantly higher $(\mathrm{P}<0.05)$ in $\mathrm{M}+\mathrm{F}$ treatment in comparison with the control (Table 3). The higher phosphorus concentration may be associated with the increase in phosphorus produced during the decomposition of organic fertilizer and also from the feed through fish excrete. Both soluble organic phosphorus and orthophosphate are released during the process of organic fertilizer decomposition under aerobic conditions (Wudtisn and Boyd, 2005; Hussein, 2009). Higher concentrations of ammonia nitrogen are often noticed in fish culture ponds (Edwards, 2008). However, the values of ammonia recorded in the present experiments were low (Table 3). Sugiyama and Kawai (1978) reported that the higher concentrations of dissolved oxygen decreases ammonia level through oxidation. These low concentrations of ammonia may be attributed to ammonia utilization by phytoplankton (Boyd, 1998) or oxidation of ammonia nitrite especially in high dissolved oxygen level conditions (Boyd, 2000). Total ammonia nitrogen fluctuated throughout experiment but remained below $1 \mathrm{mg} / \mathrm{L}$ and at the $\mathrm{pH}$ levels observed; unionized ammonia probably did not adversely affect fish performance. Major water quality parameters measured during the study remained in the favorable range for fish culture (Boyd, 1990). Comparable results were obtained by Lawson (1995). All ponds were within acceptable range of water quality parameters during the study. The Use of organic fertilizers and supplementary feed improved water quality through stimulation of natural food, mainly phytoplankton and zooplankton, suitable for the filter feeding carp species .Organic fertilizers acts as an energy source for bacterial growth, but the aerobic decomposition of organic matter by bacteria is an important drain of oxygen supplies in ponds (Boyd,1982).

Values of water temperature, $\mathrm{pH}$ and $\mathrm{DO}$ in the diurnal samples showed no effect of treatments. The increase in the values of these parameters with the progress of day and decrease with the progress of night can be related to the presence and absence of light which affects temperature and also dissolution of oxygen in pond water. Further photosynthesis during day time is responsible for the higher DO values, whereas consumption of DO by plankton reduced night time DO. Similarly, $\mathrm{pH}$ variations can also be correlated with photosynthetic activity.

\section{Plankton biomass}

Table 4 quantifies the planktonic species encountered in the tank water on the sampling days. Among phytoplankton, Chlorophyceae comprised 15 genera, the major ones being Microspora, Volvox and Scenedesmus. Cyanophyceae was represented by 3 genera, Microcystis and Anabaena being dominant. Chrysophyceae, 
Bacillariophyceae and Dinophyceae were represented by one genus each. Diaptomus, Cyclops, Moina and Keratella were the zooplankton species encountered. In addition, nauplii and insect eggs were also found in good numbers.

Table 4: Abundance of phytoplankton species in pond water (cells $/ \mathrm{L} \pm$ S.E.) during the experimental period.* (Pooled data of the two experiments)

\begin{tabular}{|c|c|c|c|c|}
\hline Group/Genus & $\begin{array}{l}\text { Control } \\
\mathrm{T} 1\end{array}$ & $\begin{array}{l}\text { Feed } \\
2\end{array}$ & \multicolumn{2}{|c|}{ Manure \pm Feed } \\
\hline \multicolumn{5}{|l|}{ PHYTOPLANKTON } \\
\hline \multicolumn{5}{|l|}{ Chlorophyceae: } \\
\hline Gleocapsa & $0.04 \pm 0.04$ & $1.12 \pm 0.46$ & $0.40 \pm 0.15$ & 00 \\
\hline Golenkinia & $3.35 \pm 0.98$ & $7.14 \pm 2.12$ & $11.52 \pm 6.51$ & $3.08 \pm 0.93$ \\
\hline Hydrodiction & 00 & $0.36 \pm 0.16$ & $0.13 \pm 0.10$ & $0.27 \pm 0.10$ \\
\hline Menoidium & 00 & 00 & $0.40 \pm 0.21$ & $0.54 \pm 0.33$ \\
\hline Ankistrodesmus & $15.09 \pm 3.10$ & $11.79 \pm 2.77$ & $16.74 \pm 4.03$ & $16.65 \pm 5.98$ \\
\hline Chlorococcum & $10.13 \pm 2.07$ & $17.54 \pm 5.92$ & $12.90 \pm 2.52$ & $31.16 \pm 15.55$ \\
\hline Closterium & $3.39 \pm 0.53$ & $2.32 \pm 0.61$ & $2.72 \pm 0.53$ & $0.45 \pm 0.18$ \\
\hline Staurastrum & $22.95 \pm 26.07$ & $32.37 \pm 4.53$ & $28.44 \pm 4.10$ & $60.00 \pm 26.70$ \\
\hline Microspora & $148.68 \pm 203.28$ & $330.67 \pm 95.78$ & $226.88 \pm 57.55$ & $484.64 \pm 109.31$ \\
\hline Pediastrum & $7.01 \pm 1.01$ & $24.20 \pm 5.82$ & $3.17 \pm 0.61$ & $10.31 \pm 3.13$ \\
\hline Phytoconis & $21.12 \pm 5.34$ & $21.12 \pm 4.97$ & $9.38 \pm 2.56$ & $22.99 \pm 3.40$ \\
\hline Scenedesmus & $59.20 \pm 24.73$ & $37.81 \pm 9.83$ & $75.85 \pm 20.18$ & $71.92 \pm 24.60$ \\
\hline Selenastrum & $67.41 \pm 18.72$ & $25.94 \pm 4.61$ & $78.08 \pm 28.80$ & $44.82 \pm 10.42$ \\
\hline Tetraedron & $35.22 \pm 10.47$ & $18.84 \pm 7.37$ & $7.05 \pm 2.34$ & $9.46 \pm 1.44$ \\
\hline Volvox & $89.87 \pm 23.83$ & $14.64 \pm 2.46$ & $25.54 \pm 7.11$ & $49.20 \pm 15.95$ \\
\hline \multicolumn{5}{|l|}{ Chrysophyceae: } \\
\hline Chrysophyxis & $3.66 \pm 1.16$ & $2.01 \pm 0.43$ & $1.47 \pm 0.34$ & $1.38 \pm 0.35$ \\
\hline \multicolumn{5}{|l|}{ Bacillariophyceae : } \\
\hline Anomoeoneis & $5.71 \pm 1.58$ & $10.18 \pm 3.26$ & $3.13 \pm 0.62$ & $3.17 \pm 0.68$ \\
\hline \multicolumn{5}{|l|}{ Dinophyceae : } \\
\hline Monomastix & $1.29 \pm 0.38$ & $0.45 \pm 0.18$ & $2.28 \pm 0.61$ & $1.21 \pm 0.31$ \\
\hline \multicolumn{5}{|l|}{ Cyanophyceae: } \\
\hline Anabaena & $541.61 \pm 205.71$ & $1654.73 \pm 366.36$ & $1550.27 \pm 325.36$ & $2213.26 \pm 314.90$ \\
\hline Merismopedia & $92.14 \pm 87.44$ & $1.43 \pm 0.33$ & $5.40 \pm 1.31$ & $3.30 \pm 0.85$ \\
\hline Microcystis & $1099.33 \pm 256.83$ & $3 \quad 2117.72 \pm 317.2$ & $12155.40 \pm 360.98$ & $2139.46 \pm 340.12$ \\
\hline Total Phytoplankton & $2227.21 \pm 513.44$ & $4 \quad 4332.37 \pm 472.8$ & $64 \quad 4217.14 \pm 628.81$ & $5167.28 \pm 530.43$ \\
\hline \multicolumn{5}{|l|}{ ZOOPLANKTON: } \\
\hline$\overline{\text { Diaptomus }}$ & $40.18 \pm 6.26$ & $52.99 \pm 12.06$ & $77.23 \pm 15.56$ & $153.70 \pm 87.27$ \\
\hline Cyclops & $23.44 \pm 3.98$ & $19.24 \pm 2.45$ & $44.46 \pm 9.81$ & $23.30 \pm 3.62$ \\
\hline Moina & $13.66 \pm 2.98$ & $7.54 \pm 1.27$ & $17.37 \pm 8.53$ & $12.86 \pm 2.16$ \\
\hline Keratella & $95.49 \pm 48.01$ & $287.54 \pm 159.98$ & $39.06 \pm 12.98$ & $456.25 \pm 220.85$ \\
\hline Insect eggs & $34.37 \pm 4.40$ & $48.70 \pm 8.61$ & $74.06 \pm 16.02$ & $55.80 \pm 12.32$ \\
\hline Nauplius & $106.70 \pm 73.96$ & $28.17 \pm 8.57$ & $386.61 \pm 248.60$ & $123.79 \pm 83.01$ \\
\hline Total Zooplankton & $313.84 \pm 90.71$ & $444.20 \pm 165.22$ & $638.79 \pm 257.65$ & $825.71 \pm 258.11$ \\
\hline
\end{tabular}

*Numbers are means of 14 samplings. Numbers in italics are standard errors.

The overall phytoplankton population was the highest under $\mathrm{M}+\mathrm{F}$ treatment (5167.28 cells /L) and the lowest in control (2227.21 cells /L). The number of green algae was lower as compared to blue-green algae in all the ponds (Table 4). The ratio between cyanophyceae and chlorophyceae was the lowest in control and highest in manure+feed $(\mathrm{M}+\mathrm{F})$ ponds. Density of phytoplankton and zooplankton (no/L) was also significantly lowest in controlponds (Table 5). The density of both phyto and zooplankton was the lowest $(\mathrm{P}<0.05)$ on the first day of sampling and highest on the $120^{\text {th }}$ day. The interaction effect of treatment and day was significant for Staurastrum $(\mathrm{P}=0.0197)$ and nauplii $(\mathrm{P}=0.007)$. 
Dry weight of phytoplankton was highest under feed (F) treatment and lowest in control. The values in manure $(\mathrm{M})$ and $\mathrm{M}+\mathrm{F}$ treatments were almost similar (Table $5)$, whereas the highest dry weight of zooplankton was observed under $M+F(2.15$ $\mathrm{mg} / \mathrm{L})$ treatment, followed by manure $(1.69 \mathrm{mg} / \mathrm{L})$, feed $(1.65 \mathrm{mg} / \mathrm{L})$ and control $(0.77 \mathrm{mg} / \mathrm{L})$. Significant $(\mathrm{P}<0.05)$ variation in both phyto and zooplankton dry weight was recorded over the experimental period, both being the lowest on zero day and highest on $120^{\text {th }}$ day.

Significant $(\mathrm{P}<0.05)$ variation in both phytoplankton and zooplankton dry weight was recorded with respect to study period. The interaction effect of treatment and day was also significant for both phytoplankton and zooplankton. The number of green algae was lower as compared to blue-green algae in all the experimental ponds. In fish ponds, blue green algae constitute the greater part of phytoplankton; higher alkalinity, nitrate, ammoniaand phosphate favour the multiplication of cyanophyceae (Padmavathi and Veeraiah, 2009). Kulkarni (1992), who studied the effect of distillery waste on plankton and fish production, reported a significant $(\mathrm{P}<0.05)$ correlation between phosphorus level and blue green algae production.

Table 5: Plankton biomass and density ( \pm S.E.) in experimental ponds (Pooled data of the two experiments)

\begin{tabular}{|c|c|c|c|c|}
\hline \multirow[t]{2}{*}{ Treatment } & \multicolumn{2}{|c|}{ Dry weight $(\mathrm{mg} / \mathrm{L})$} & \multicolumn{2}{|l|}{ Density (no/L) } \\
\hline & Phytoplankton & Zooplankton & Phytoplankton & Zooplankton \\
\hline Control & $0.77 \pm 0.14 b$ & $0.77 \pm 0.24 \mathrm{c}$ & $2227.21 \pm 513.44 b$ & $313.84 \pm 90.71 \mathrm{a}$ \\
\hline Feed & $1.98 \pm 0.27 \mathrm{a}$ & $1.65 \pm 0.15 b$ & $4332.37 \pm 472.86 a$ & $444.20 \pm 165.22 \mathrm{a}$ \\
\hline Manure & $1.73 \pm 0.24 \mathrm{a}$ & $1.69 \pm 0.17 \mathrm{~b}$ & $4217.14 \pm 628.81 \mathrm{a}$ & $638.79 \pm 257.66 a$ \\
\hline Manure \pm Feed & $1.70 \pm 0.25 a$ & $2.15 \pm 0.24 a$ & $5167.28 \pm 530.43 a$ & $825.71 \pm 258.11 a$ \\
\hline
\end{tabular}

Different superscripts for values in the same column indicate significant $(\mathrm{P}<0.05)$ difference.

Rahman et al. (2008) reported that the common carp increased bio-available $\mathrm{N}$ and $\mathrm{P}$ in the water column and plankton where availability was positively correlated with bio-available $\mathrm{N}$ and $\mathrm{P}$. The relationship between provision of manure/feed and plankton biomass observed in the present study can be related to the nutrient input. In addition, fish excretion would have contributed to the level of $\mathrm{N}$ and $\mathrm{P}$ in pond water, particularly towards the later part of the experiment.

\section{Fish growth, survival and production}

The final weight and length of fish in experiments one and two are given in Tables (6 and 7). The highest final weight was observed in T4 treatment in both the experiments. Growth was similar in $\mathrm{F}$ and $\mathrm{M}$ treatments in experiment one, but significantly $(\mathrm{P}<0.05)$ different in experiment two.

Table 6: Growth parameters (average \pm S.E.) of common carp fry under different treatments (Experiment one)

\begin{tabular}{|l|l|l|l|}
\hline Parameter & $\begin{array}{l}\text { Control } \\
\text { T1 }\end{array}$ & $\begin{array}{l}\text { Feed } \\
\text { T2 }\end{array}$ & $\begin{array}{l}\text { Manure } \\
\text { T3 }\end{array}$ \\
\hline $\begin{array}{l}\text { Final weight (g)/fish } \\
\text { Increment in growth over }\end{array}$ & $18.16 \pm 1.15 \mathrm{~b}$ & $35.86 \pm 0.22 \mathrm{a}$ & $36.84 \pm 4.50 \mathrm{a}$ \\
control (\%) & - & 97.46 & $43.43 \pm 2.02 \mathrm{a}$ \\
Final length (cm) & $11.41 \pm 0.7 \mathrm{~b}$ & $14.05 \pm 0.20 \mathrm{a}$ & 102.86 \\
SGR (\%) & $2.75 \pm 0.09 \mathrm{~b}$ & $3.32 \pm 0.02 \mathrm{a}$ & $12.78 \pm 0.50 \mathrm{ab}$ \\
$\begin{array}{l}\text { Survival (\%) } \\
\text { Production } \\
\text { (kg/pond/ } 4 \text { month) }\end{array}$ & $57.58 \pm 7.57 \mathrm{a}$ & $61.20 \pm 14.2 \mathrm{a}$ & $52.12 \pm 12.76 \mathrm{a}$ \\
$\begin{array}{l}\text { Increment in production } \\
\text { overcontrol (\%) }\end{array}$ & $1725.39 \pm 105.72 \mathrm{c}$ & $3506.40 \pm 91.85 \mathrm{~b}$ & $3059.04 \pm 38.95 \mathrm{~b}$ \\
\end{tabular}

Different superscripts for values in the same column indicate significant $(\mathrm{P}<0.05)$ difference. 
Fish growth was significantly $(\mathrm{P}<0.05)$ poor in the control in both the experiments. SGR values followed the trend of fish growth at harvest.

The overall survival varied from $52.12 \%$ in $\mathrm{T} 3$ treatment to $63.03 \%$ in $\mathrm{T} 4$ treatment in experiment one, while it was in the range of $61.67 \%$ (T4) to $82.78 \%$ (T3) in experiment two. However, difference in survival among the control and the treatments was not significant $(\mathrm{P}>0.05)$ in experiment one. Net production in this experiment varied from 1725.39 (control) to $4524.63 \mathrm{~g} /$ pond $/ 120$ days (T4 treatment).

In T2 and T3 treatments production was nearly equal, being significantly $(\mathrm{P}<0.05)$ higher in the control and lower in $\mathrm{T} 4$ treatment (Table 6). In experiment two, the net production was higher compared to experiment one (2518.20 to 6927.03 $\mathrm{g} /$ pond/120 days) and varied significantly between the control and all treatments (Table 7), while manuring, individually and in combination, improved the growth of fish significantly $(\mathrm{P}<0.05)$ in both the experiments (Tables 6 and 7). The highest final weight was recorded in $M+F$ (T4) treatment. Specific growth rate followed the growth trend in both the experiments, while there was no difference in growth of fish between feed (F T2) and (M T3) treatments in experiment one, as it differed significantly $(\mathrm{P}<0.05)$ in experiment two. Growth under $\mathrm{F}, \mathrm{M}$ and $\mathrm{M}+\mathrm{F}$ treatment in experiment one works out to $97.46 \%, 102.86 \%$, and $139.15 \%$ higher respectively over the control. The corresponding values in experiment two are 152\%, 36.20\% and $184.78 \%$. It is clear that feed treatments $(\mathrm{F}$ and $\mathrm{M}+\mathrm{F})$ had greater impact on the growth of fingerlings as compared to fry; fingerlings are better equipped in terms of mouth size and digestive enzymes to accept and utilize pelleted diet (Woynarovich, et al. 2011). Further, a comparison of the final weights of fish from experiment one with that of experiment two, points out to the difference in growth rate due to life stage. The increase in weight of control fish is only $1.62 \mathrm{~g}$, whereas under manure

Table 7: Growth parameters (average \pm S.E.) of common carp fingerlings under different treatments (Experiment two)

\begin{tabular}{|l|l|l|l|l|}
\hline Parameter & $\begin{array}{l}\text { Control } \\
\mathrm{T} 1\end{array}$ & $\begin{array}{l}\text { Feed } \\
\mathrm{T} 2\end{array}$ & $\begin{array}{l}\text { Manure } \\
\mathrm{T} 3\end{array}$ & $\begin{array}{l}\text { Manure+Feed } \\
\mathrm{T} 4\end{array}$ \\
\hline Initial weight(g)/fish & $3.21 \pm 0.41 \mathrm{a}$ & $3.19 \pm 0.41 \mathrm{a}$ & $3.22 \pm 0.41 \mathrm{a}$ & $3.18 \pm 0.41 \mathrm{a}$ \\
Final weight (g)/fish & $19.78 \pm 0.82 \mathrm{~d}$ & $49.87 \pm 1.62 \mathrm{~b}$ & $26.94 \pm 1.48 \mathrm{c}$ & $56.33 \pm 2.75 \mathrm{a}$ \\
Increment in growth over control (\%) & & & \\
Initial length (cm) & - & 152.12 & 36.20 & 184.78 \\
Final length (cm) & $5.20 \pm 0.21 \mathrm{a}$ & $5.23 \pm 0.21 \mathrm{a}$ & $5.23 \pm 0.21 \mathrm{a}$ & $5.22 \pm 0.21 \mathrm{a}$ \\
SGR (\%) & $9.50 \pm 1.14 \mathrm{c}$ & $13.70 \pm 1.01 \mathrm{a}$ & $12.25 \pm 0.50 \mathrm{~b}$ & $14.07 \pm 0.81 \mathrm{a}$ \\
Survival (\%) & $1.52 \pm 0.03 \mathrm{~b}$ & $2.29 \pm 0.03 \mathrm{a}$ & $1.77 \pm 0.04 \mathrm{~b}$ & $2.62 \pm 0.27 \mathrm{a}$ \\
Production (kg/pond/4 months) & $70.55 \pm 2.94 \mathrm{ab}$ & $68.89 \pm 6.83 \mathrm{~b}$ & $82.78 \pm 0.55 \mathrm{a}$ & $61.67 \pm 2.55 \mathrm{~b}$ \\
Increment in production & $2518.20 \pm 63.85 \mathrm{~d}$ & $5540.01 \pm 107.22 \mathrm{~b}$ & $4015.11 \pm 70.33 \mathrm{c}$ & $6927.03 \pm 141.09 \mathrm{a}$ \\
over control (\%) & - & 119.99 & 59.44 & 175.08 \\
\hline
\end{tabular}

Different superscripts for values in the same column indicate significant $(\mathrm{P}<0.05)$ difference.

treatment $(\mathrm{M})$, there is a reduction of $9.9 \mathrm{~g}$. Asagainst this, in fed treatments there is an increase of 14.01g (F) and $12.9 \mathrm{~g}(\mathrm{M}+\mathrm{F})$ (Tables 6 and 7). This result showed that the nutrient requirement of fingerlings is not satiated by natural food alone, contrary to that in the case of fry. Boyd (1990) reported a strong positive correlation between fish growth and primary productivity in fertilized ponds without supplementary feeding. Natural food is nutritive and contains $51.1 \%$ protein, $27.3 \%$ carbohydrate and $7.7 \%$ fat, while the calorific value ranges from 6.7 to $23.8 \mathrm{~kJ} / \mathrm{g}$ (De Silva and Anderson, 1995). It is possible that as the fish grows bigger, it prefers artificial diet when available. Rahman et al. (2008) observed that common carp growth, in polyculture with rohu, Labeo rohita, was higher in the presence ofartificial feed and 
negatively correlated with natural food availability. They also recorded higher ingestion of benthic macroinvertebrates, copepods and rotifers, and a lower ingestion of phytoplankton by common carp.

In the ponds receiving no supplementary feed, the growth obtained is entirely attributable to the natural food. This applies to the control as well as manure (M) treatment. In experiment one, growth of fish in $M$ treatment was double that of control, reflecting the ability of common carp fry to extensively feed on the available natural food and convert it into flesh. Though the control ponds did not receive any nutrient input during the experiment. The soil bottom of all ponds used in the present study contained some nutrients accumulated from earlier trials; the effect of these could be considered as equal under all treatments. Common carp as a bottom feeding fish enhances the availability of nutrients to phytoplankton through stirring of the mud bottom (Milstein et al., 2002). Ritvo et al. (2004) demonstrated that common carp by perturbations results in appreciable mixing of the sediment; this mixing would bring out nutrients into circulation, facilitating natural food production.

The difference in survival of fish in the control and treatment ponds was not significant $(\mathrm{P}>0.05)$ in the first experiment, whereas feed treatments $(\mathrm{F}$ and $\mathrm{M}+\mathrm{F})$ recorded lower survival $(\mathrm{P}<0.05)$ in the second experiment. This could be due to some natural mortality of fish in ponds of the two treatments, since water quality was similar in all treatments, but for higher alkalinity and phosphate levels in $\mathrm{M}+\mathrm{F}$ treatment. Gross fish production was influenced both by fish weight and survival. Production was the highest in $\mathrm{M}+\mathrm{F}$ treatment in both the experiments. In experiment one, production was comparable $(\mathrm{P}>0.05)$ in $\mathrm{F}$ and $\mathrm{M}$ treatments. The increment in gross fish production over the control was $103.22 \%$ in $\mathrm{F}, 77.30 \%$ in $\mathrm{M}$ and $162.34 \%$ in $\mathrm{M}+\mathrm{F}$ treatments (Table 6). In experiment two, production was significantly $(\mathrm{P}<0.05)$ higher in the feed treatment $(\mathrm{F})$ compared to the manure $(\mathrm{M})$ treatment, again indicating the significance of feeding in the case of fingerlings. The corresponding figures of increment for experiment two are $119.99 \%, 59.44 \%$ and 175.08\% (Table 7). Abbas et al. (2010) and Priyadarshinil et al. (2011) reported highest gross productionof carps in the treatment with the combination of organic and inorganic fertilizers and supplementary feeding, compared to combinations of any two of these.

\section{Proximate composition}

The proximate composition of fish carcass from experiment one is shown in Table (8). Crude protein, fat and ash contents were significantly $(\mathrm{P}<0.05)$ higher in the 3 treatments compared to the control. No difference was found between the crude protein content of $\mathrm{F}$ and $\mathrm{M}$ treatments and fat content of $\mathrm{F}, \mathrm{M}$ and $\mathrm{M}+\mathrm{F}$ treatments.

Table 8: Proximate composition of fish (\% wet weight)

\begin{tabular}{|l|l|l|l|l|}
\hline Parameter & $\begin{array}{l}\text { Control } \\
\text { T1 }\end{array}$ & $\begin{array}{l}\text { Feed } \\
\text { T2 }\end{array}$ & $\begin{array}{l}\text { Manure } \\
\text { T3 }\end{array}$ & $\begin{array}{l}\text { Manure+Feed } \\
\text { T4 }\end{array}$ \\
\hline Moisture & $73.50 \pm 2.60 \mathrm{a}$ & $70.19 \pm 2.03 \mathrm{a}$ & $68.90 \pm 2.99 \mathrm{a}$ & $70.72 \pm 1.71 \mathrm{a}$ \\
Crude protein & $17.21 \pm 0.08 \mathrm{c}$ & $19.20 \pm 0.05 \mathrm{~b}$ & $19.27 \pm 0.06 \mathrm{~b}$ & $21.60 \pm 0.07 \mathrm{a}$ \\
Fat & $1.08 \pm 0.06 \mathrm{~b}$ & $1.35 \pm 0.02 \mathrm{a}$ & $1.31 \pm 0.11 \mathrm{a}$ & $1.36 \pm 0.04 \mathrm{a}$ \\
Ash & $5.78 \pm 0.02 \mathrm{c}$ & $6.16 \pm 0.01 \mathrm{~b}$ & $6.54 \pm 0.01 \mathrm{~b}$ & $6.13 \pm 0.03 \mathrm{a}$ \\
\hline
\end{tabular}

Different superscripts for values in the same column indicate significant $(\mathrm{P}<0.05)$ difference. Initial weight and length of fry were $0.67+0.06 \mathrm{~g}$ and $2.32+0.11 \mathrm{~cm}$ respectively.

Proximate analysis of fish carcass revealed that the treatments affected crude protein and fat, both being lowest in control and highest in $\mathrm{M}+\mathrm{F}(\mathrm{T} 4)$ treatment. However, there was no difference in moisture level among the treatments and control (Table 8).This is indicative of protein accretion and true growth involving an increase 
in the structural tissue such as muscle and various organs (Fafioye et al., 2005). The type of feed ingested and their nutritional quality is known to be one of the main factors affecting fish carcass composition (Reinitz and Hitzel, 1980; Priyadarshini1 et al. 2011).

The results obtained in this study clearly point out to the importance of natural food in fish culture. Growth of fish in experiment one indicates similar potential of poultry manure and the feed provided in inducing growth of common carp fry. In contrast, fish growth in experiment two was significantly better under fed treatments ( $\mathrm{F}$ and $\mathrm{M}+\mathrm{F}$ ). This shows that nutritional requirement of common carp fingerlings is not fully met by natural food alone, contrary to that of fry. The findings can be used in developing feedingstrategy for fish at different life stages during culture.

\section{REFERENCES}

Abbas, S.; Ahmed, I.; Salim, M. and Rehman, K.( 2010). Comparative effects of fertilization and supplementary feed on growth performance of three fish species. Int. J. Agricult. Biology., 12(2): 276-280.

Afzal, M., Rub, V.; Akhtar, N.; Khan, M. F.; Barlas, A. and Qayyum, M. (2007). Effect of organic and inorganic fertilizers on the growth performance of bighead carp (Aristicthys nobilis) in polyculture system. Int. J. Agric. Biol., 9: 931-933

Ahmed, I.; Abbas, K. and ur-Rehman, H. M. (2005). Growth response of major carps in semi-intensive ponds supplemented with rice polishing. Pakistan Vete. J., 25(2): 59-62.

Alim, M.A.; Wahab, M.A. and Milstein, A. (2005). Effects of increasing the stocking density of large carps by $20 \%$ on 'cash' carp-small fish polyculture of Bangladesh. Aquacult. Res., 36: 317-325

AOAC, (1995). Official Methods of Analysis of AOAC International, In: P.A. Cunniff, (Ed.), AOAC International, $16^{\text {th }}$ Ed. Arlington, USA.

APHA/AWWA/WEF (2000). Standard Methods for the Examination of Water and Wastewater, $21^{\text {th }}$ Ed. L.S., Clesceri, A.E., Greenberg and A.D. Eaton, (Eds.), American Public Health Association / American Water Works Association / Water Environment Federation, Washington, DC.

Azim, M. E.; Verdegem M. C. J.; Rahman, M.M.; Wahab M.A.; Van Dam, A. A. and Beveridge, M.C.M. (2002). Evaluation of polyculture of Indian major carps in periphyton based ponds. Aquacult., 213: 131-149

Aziz, H.; Javed, M. and Kazimi, R. (2002). Studies on the growth performance of major carps in poultry droppings fertilized ponds supplemented with feed. J. Animal and Veterinary Advances, 1(3): 113-115.

Bhakta, J.N.; Sarkar, D.; Jana, S. and Jana, B. B. (2004). Optimizing fertilizer dose for rearing stage production of carps under polyculture. Aquacult., 239: 125-139.

Bhakta, J. N.; Bandyopadhyay, P. K. and Jana, B. B. (2006). Effect of different doses of mixed fertilizer on some biogeochemical cycling bacterial population in carp culture pond. Tur. J. Fish. Aqua. Sci., 6:165-171.

Boyd, C. E. (1982).Water Quality Management For Pond Fish Culture. Elsevier Scientific Publishing Company, New York, NY,318 pp.

Boyd, C. E., (1990). Water quality in ponds for aquaculture. Alabama Agriculture Experiment Station Auburn Univ., Alabama, Birmingham Publishing Co. 482 pp. 
Boyd, C. E. (1998). Water quality for pond aquaculture. Research and development series No.43. pp37. International Center for Aquaculture and Aquatic Environments. Alabama Agriculture Experiment Station. Auburn Univ.

Boyd, C. E. (2000). Water Quality: An Introduction. Kluwer Academic published Bosto, Massachusetts.

Bwala, R.L. and Omoregie, E. (2009). Organic enrichment of fish ponds: application of pig dung vs. tilapia yield. Pakistan Journal of Nutrition, 8(9): 1373-1379.

Da Silva, L. B.; Barcellos L. J. G.; Quevedo R. M.; de Souza S. M. G.; Kreutz L. C.; Ritter F.; Finco J. A. and Bedin A. C. (2006). Alternative species for traditional carp polyculture in southern, South America: Initial growing period. Aquacult., 255: 417-428.

Das, P.C.; Ayyappan, S. and Jena, J. (2005). Comparative changes in water quality and role of pond soil after application of different levels of organic and inorganic inputs. Aquaculture Research (CIFA), 36: 785-798.

De Silva, S. S. and Anderson, T.A. (1995). Fish Nutrition in Aquaculture. Chapman and Hall, London, 319 pp.

Dhawan, A. and Kaur, S. (2002). Pig dung as pond manure: Effect on water quality, pond productivity and growth of carps in polyculture system. Naga, 25: 11-14.

Diana, J. S.; Lin, C. K. and Jaiyen, K. (1994). Supplemental feeding of tilapia in fertilized ponds. J. World Aquacult. Soc., 25: 497-506

Duncan, D.B. (1955). Multiple range and multiple F-tests.Biometrics, 11: 1-42.

Edwards, P. (2008). Inland aquaculture: comments on possible improvements to carp culture in Andhra Pradesh. Aquaculture Asia Magazine, 13(3): 3-7.

Elnady, M.A.; Alkobaby, A.I.; Salem, M.A.; Abdel-Salam, M. and Asran, B. M. (2010). Effect of fertilization and low quality feed on water quality dynamics and growth performance of Nile tilapia (Oreochromisniloticus). Journal of American Science, 6(10): 1044- 1054.

Fafioye, O.O.; Fagade, S.O.; Adebisi, A.A.; Jenyo, O. and Omoyinmi, G.A.K. (2005). Effects of dietary soybeans (Glycine max (L.) Merr.) on growth and body composition of African catfish (Clarias gariepinus, Burchell) fingerlings. Turkish Journal of Fisheries and Aquatic Sci., 5(1): 11-15.

Farmanfarmaian, A. and Moore, R. (1979). Diseasonal thermal aquaculture-1. Effect of temperature and dissolved oxygen on survival and growth of Macrobrachium rosenbergii. In: Power Plant Waste Heat Utilization in Aquaculture. Final Report, March, 1980. NSF/RANN (ASRA/PFRA).

Garg, S. K. and Bhatnagar, A. (2000). Effect of fertilization frequency on pond productivity and fish biomass in still water pond stocked with Cirrhinus mrigala (Ham.). Aquacult. Res. (CIFA),31: 353-369.

Hargreaves, J.A. (1998). Nitrogen biogeochemistry of aquaculture ponds. Aquacult., 166: $181-212$.

Hastings W.H. (1976). Fish nutrition and fish feed manufacture.Paper presented at FAO technical conference on Aquaculture, Kyoto, Japan,13 pp.

Huet, M. (1972). Textbook of Fish Culture-Breeding and Cultivation of Fish. Fishing News (Books), Ltd., London, 436 pp.

Hussein, M.S. (2009). Comparative effects of fertilization and supplementary feed with rice bran on growth performance, water quality parameters and economic returns of the fish under polyculture ponds. J. Product. \& Dev., 15(3):251-277.

Islam, M. S. (2002). Evaluation of supplementary feed for semi-intensive pond culture mahseer, Tor putitora (Hamilton). Aquacult., 212: 263-276. 
Jain, Z. (2002). Status of carp varieties under culture in China. Aqua. Asia., 7(1): 27-28.

Jana, B.B.; Chakrabarty, P.; Biswas, J. K. and Ganguly, S. (2001). Biogeochemical cycling bacteria as indices of pond fertilization: Importance of CNP ratios of input fertilizers. J. Appl. Microbiol., 90: 733-740

Jhingran, V.G.; Natarajan, A.V.; Banerjea, S.M. and David, A. (1969). Methodology on reservoir fisheries investigations in India. Bulllletin of the Central Inland Fisheries Research Institute, Barrackpore, 109 pp.

Jhingran, V. G. (1995). Fish and Fisheries of India, p:954. Hindustan Publishing (India).

Jiménez-Montealegre, R. (2001). Nitrogen transformation and fluxes in fish ponds: A modelling approach. $\mathrm{PhD}$ thesis. Wageningen: Wageningen University.

Jobling M. (1983). A short review and critique of methodology used in fish growth and nutrition studies. J. Fish Biology, 23: 686-703.

Kulkarni, V. (1992). Use of distillery waste for fish culture. MSc thesis. Bangalore: University of Agricult. Sci.

Kumar, M.S.; Binh, T.T.; Burgess, S.N. and Luu, L.T. (2005). Evaluation of optimal species ratio to maximize fish polyculture production. J. Applied Aquacult., 17(1):35-49.

Lawson, T. B. (1995). Fundamentals of aquaculture engineering. Chapman \& Hall. An International Thomson Publishing Company. New York. USA.

Muhammad, N.; Muhammad, A.; Sumaira, A.; Iftikhar, A.; Muhammad, A. and Muhammad, H. (2011). Growth performance of common carp (Cyprinus carpio) in response to organic fertilizers and supplementary feed .Greener Journal of Agricult. Sci., 1(2): 032- 040.

Mayes, P.A. (1990). Nutrition, In: R.K. Murray, D.K. Graner, P.A. Mayes and V.W. Rodwell (Eds.) Harper's Biochemistry 22nd Ed. Prentice Hall International Inc., USA., 571-579.

Milstein, A.; Alkon, A.; Avnimelech, Y.; Kochba, M.; Hulata, G. and Schroeder, G. (2003). Effect of manuring rate on ecology and fish performance in polyculture ponds. Aquacult., 96: 119-138

Milstein, A.; Wahab, M. A. and Rahman, M. M. (2002). Ecological effects of common carp Cyprnus carpio (L.) and mrigal Cirrhinus mrigala (Hamilton) as bottom feeders in major Indian carp polycultures. Aquacult. Res., 33: 1103-1117.

Moav, R.; Wohlfarth, G.; Shroeder, G.L.; Hulata, G. and Barash, H. (1977). Intensive polyculture of fish in freshwater ponds. 1. Substitution of expensive feeds by liquid cow manure. Aquacult., 10: 25-43.

NACA/FAO, (2000). Aquaculture Development Beyond 2000: The Bangkok Declaration and Strategy. Proceedings of the Conference on Aquaculture in the Third Millennium, 20-25 February 2000, Bangkok, Thailand. NACA, Bangkok and FAO, Rome, 471 pp. Padmavathi, P. and Veeraiah, K. 2009. Studies on the influence of Microcystis aeruginosa on the ecology and fish production of carp culture ponds. African J. Biotechnology, 8(9): 1911-1918.

Nandeesha, M. C.; Gangadhara, B.; Manissery, J. K. and Venkataraman, L. V. (2001). Growth performance of two Indian major carps, catla (Catlacatla) and rohu (Labeo rohita) fed diets containing different levels of Spirulina platensis. Bioresour. Technol., 80: 117-120

New, M. and Fedoruk, K. (2003). Reports on the Regional Workshop on Aquacult. Planning in Asia, Bangkok, Thialand, 154pp. 
Padmavathi, P. and Veeraiah, K. (2009). Studies on the influence of Microcystis aeruginosa on the ecology and fish production of carp culture ponds. African Journal of Biotechnology, 8(9): 1911-1918.

Ponce Palafox, J. T. (2010). The effect of chemical and organic fertilization on phytoplankton and fish production in carp (Cyprinidae) polyculture system.

Revista Biociencias Julio (2010). Vol. 1 Núm. 1 Año 1 Páginas 44 a 50

Priyadarshini1, M.; Manissery, J.K.; Gangadhara, B. and Keshavanath, P. (2011). Influence of Feed, Manure and Their Combination on The Growth of Cyprinus carpio (L.) Fry and Fingerlings Turkish J. Fish. Aquatic Sci., 11: 577-586

Rahman, M. M.; Verdegem, M.C.J.; Nagelkerke, L.A.J.; Wahab, M.A.; Milstein, A. and Verreth, J. A. J. (2006). Growth, production and food preference of rohu Labeo rohita $(\mathrm{H}$.$) in monoculture and in polyculture with common carp$ Cyprinus carpio (L.) under fed andnon- fed ponds. Aquacult., 257: 359-372

Rahman, M. M.; Nagelkerke, L. A. J.; Verdegem, M.C.J.; Wahab, M. A. and Verreth, J. A. J. (2008). Relationships among water quality, food resources, fish diet and fish growth in polyculture ponds: A multivariate approach. Aquacult., 275: 108-115.

Reinitz, G. and Hitzel, F. (1980). Formulation of practical diets for rainbow trout based on desired performance and body composition. Aquacult., 19:243-252.

Rick, W. and Stegbaurer, H. P. (1974). Alpha amylase measurement of reducing groups. In: H.V. Bergmeyer (Ed.), Methods of Enzymatic Analysis, 2 Ed., Academic Press, New York: 885-889.

Ritvo, G.; Kochba, M. and Avnimelech, Y. (2004). The effects of common carp bioturbation on fishpond bottom soil. Aquacult., 242: 345-356.

Saikia, S. K. and D.N. Das, (2008). Feeding ecology of common carp (Cyprinus carpio 1.) in a rice-fish culture system of the apatani plateau (Arunachal Pradesh, India), Aquatic. Ecology, 10.1007/s10452-008-9174-y.

SAS. (2005). Statistical Analyses Systems. SAS Program ver.9.1,SAS institute incorporation, Cary, NC27513USA

Sayeed, M. A.; Alam, M. T.; Sultana, S.; Ali, M.S.; Azad, M.S. and Islam, M.A. (2007). Effect of inorganic fertilizer on the fish growth and production in polyculture system of Bangladesh. University Journal of Zoology, Rajshahi University, 26: 77-80. Aquacult. Extension Manual, No. 2, New Series, 38 pp.

Silva, S.S. and Anderson T.A. (1995). Fish Nutrition in Aquaculture. Chapman and Hall Publication, New Delhi, India.

Sugiyama, M. and Kawai, A. (1978). Microbiological studies on the nitrogen cycle in aquatic environments. 4. Metabolic rate of ammonium nitrogen in freshwater regions. Bulletin of the Japanese Society of Scientific Fisheries, 44: 351-355.

Sun, W.; Dong, S.; Zhao, X.; Jie, Z.; Zhang, H. and Zhang, L. (2010). Effects of zooplankton refuge on the growth of tilapia (Oreochromis niloticus) and plankton dynamics in pond. Aquacult. Int., 18: 647-655

Tabinda, A. B. and Ayub, M. (2009). Effect of high phosphate fertilization rate on pond phosphate concentrations, chlorophyll a, and fish growth in carp polyculture. Aquacult. Int., 9: 9243-9249

Tabinda, A. B. and Ayub M. (2010). Effect of high phosphate fertilization rate on pond phosphate concentrations, chlorophyll a, and fish growth in carp polyculture. Aquacult. Int., 18: 285-301

Teichert-Coddington, D. and Green, B.W. (1993). Tilapia yield improvement through maintenance of minimal oxygen concentrations in experimental grow-out ponds in Honduras. Aquacult., 118: 63-71. 
Virk, P. and Saxena, P.K. (2003). Potential of Amaranthus seeds in supplementary feed and its impact on growth in some carps. Bioresource Technology, 86(1):25- 27

Wahab, M. A.; Rahman, M. M. and Milstein, A. (2002). The effect of common carp, Cyprinus carpio (L.) and mrigal, Cirrhinus mrigala (Hamilton) as bottom feeders in major Indian carp polycultures. Aquacult. Res., 33: 547-556

Waidbacher, H.; Liti, D. M.; Fungomeli, M.; Mbaluka, R. K.; Munguti, J. M. and Straif, M. (2006). Influence of pond fertilization and feeding rate on growth performance, economic returns and water quality in a small-scale cage-cumpond integrated system for production of Nile tilapia (Oreochromis niloticus L.) Aquacult. Res., 37: 594-600.

Woynarovich, A.; Bueno, P. B.; Altan, Ö.; Jeney, Zs.; Reantaso, M.; Xinhua, Y. and Van Anrooy R. (2011). Better Management Practices for Carp Production in Central and Eastern Europe, the Caucasus and Central Asia. FAO Fisheries and Aquacult. Tech. Paper. No 566. Ankara, FAO. 2011.153 pp.

Wudtisin, W. and Boyd, C. E. (2005). Determination of the phosphorus fertilization rate for bluegill ponds using regression analysis. Aquacult. Res.,36:593-599.

\section{Arabic Summary}

\section{تأثثير التذذية، والروث، والجمع بينهما على نمو يرقات و أصبعيات سمك المبروك العادى(سيبرينس كاربيو)

$$
\text { قسم الإنتاج الحيو اني ( شعبة الإنتاج السمكي) ـليةلين حسلزر اعة - جامعةالأز هر - مصر. }
$$

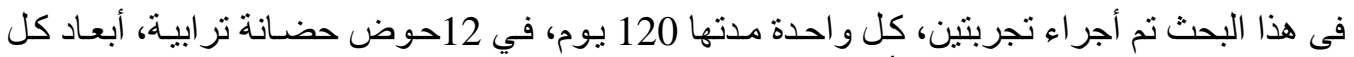

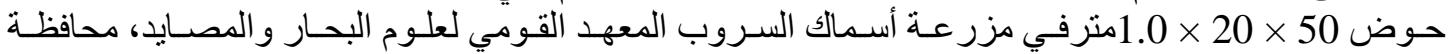

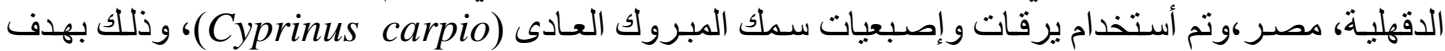

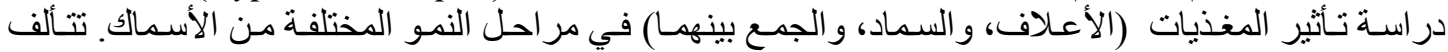

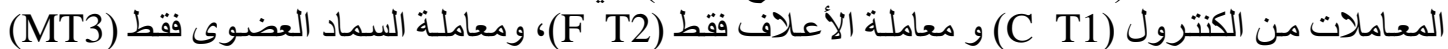

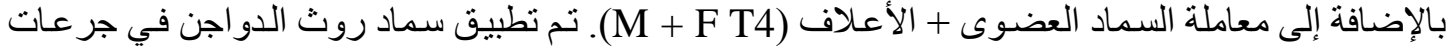

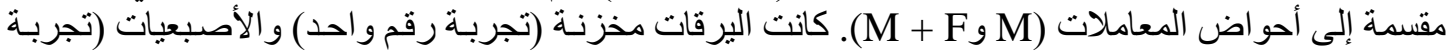

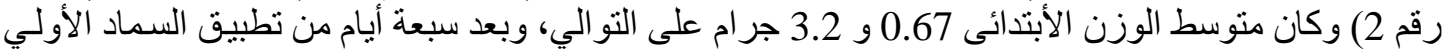

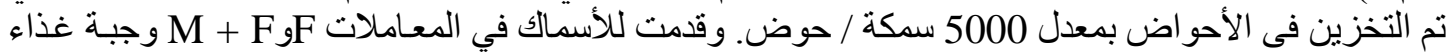

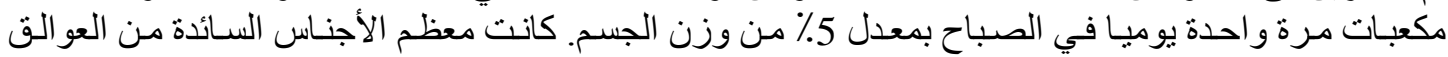

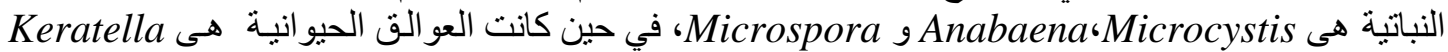

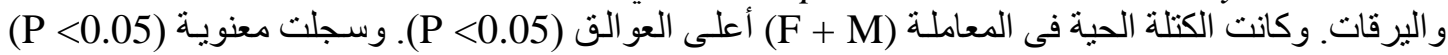

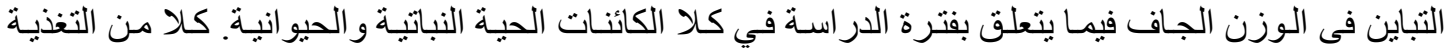

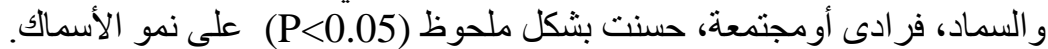

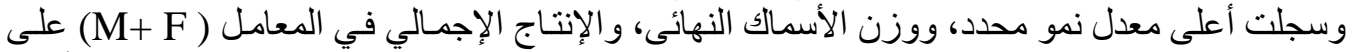

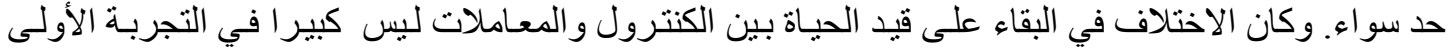

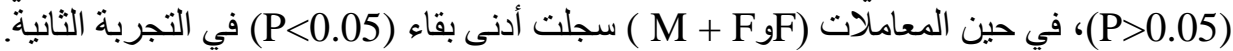

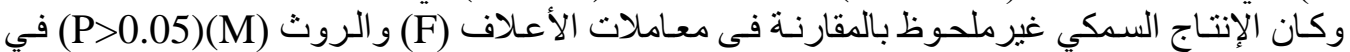

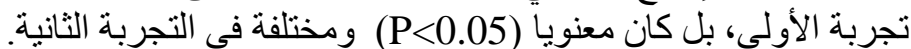

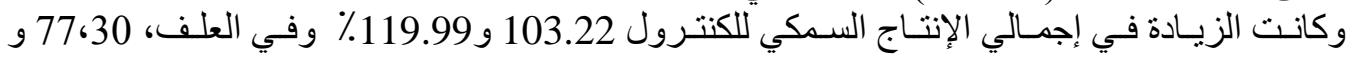

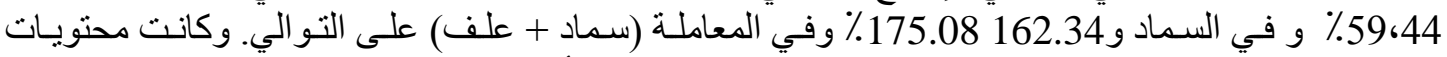

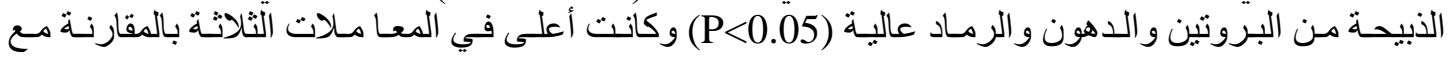

